\title{
Spatio-temporal variation in sediment biochemistry alters larval habitat selection and juvenile performance in the polychaete Capitella sp. I
}

\author{
V. Thiyagarajan ${ }^{1}$, L. Soo ${ }^{1}$, P. K. S. Shin ${ }^{2}$, P. Y. Qian ${ }^{1, *}$ \\ ${ }^{1}$ Department of Biology/Coastal Marine Laboratory, Hong Kong University of Science and Technology, Kowloon, \\ Hong Kong, SAR \\ ${ }^{2}$ Centre for Coastal Pollution and Conservation, City University of Hong Kong, Kowloon, Hong Kong, SAR
}

\begin{abstract}
The aim of the present study was to understand how larvae and juveniles of the opportunistic polychaete Capitella sp. I respond to natural sediments with varying biochemical properties. Muddy sediments of a similar particle size spectrum were collected from 5 sites in Hong Kong along a pollution gradient of domestic sewage on 4 sampling occasions in both wet and dry seasons. The sediments were used to study the influence of organic matter quantity and composition (i.e. total organic carbon [TOC], total nitrogen [TN], chlorophyll $a$, biopolymeric carbon and enzymatically hydrolysable amino acid contents) on larval metamorphosis (i.e. habitat selection) and juvenile performance (i.e. growth and survivorship). Organic matter quantity and composition varied with sampling date and site. Still water multiple-choice experiments showed that larval choice at settlement varied with spatial and temporal variations in sediment biochemical properties. A series of experiments in the study also showed that both the quantity and the composition of organic matter affect the attractiveness of substrates to larvae and appear to play a key role in determining larval behavior at the time of settlement. Further laboratory experiments showed that larvae did not choose to settle on sediments from sites where juvenile growth was poor and mortality was higher. Our field data indicated that both larval metamorphosis and juvenile performance patterns observed in this laboratory study partially corroborate data on the abundance of adult Capitella spp. in the field. Overall, this study suggests that the field distribution of Capitella sp. I, and consequently species composition in a community, could be determined by the habitat selection by larvae and early juvenile performance.
\end{abstract}

KEY WORDS: Capitella sp. I - Larval metamorphosis - Sediment organic matter - Juvenile growth · Survival

\section{INTRODUCTION}

The polychaete Capitella sp. I is an opportunistic deposit feeder found in great abundance in disturbed or organically enriched sediments and is therefore often employed as a bioindicator of organic pollution (Grassle \& Grassle 1976). The life cycle of this species includes a pelagic larval stage and a benthic adult stage. Over the past several years, its adult growth and reproductive responses to a variety of environmental factors have been extensively studied (e.g. Linton \&
Taghon 2000 and references therein), but only a few studies have closely examined its larval metamorphosis (Butman \& Grassle 1992, Grassle et al. 1992, Snelgrove et al. 1993, 2001, Cohen \& Pechenik 1999). Limited studies thus far have demonstrated that larvae of Capitella sp. I require specific sediment-bound chemical cues for settlement and metamorphosis. However, the precise nature of these settlement cues and the mechanisms involved in the larval settlement of this ecologically important species remain largely unknown (Marinelli \& Woodin 2004). 
Settlement of the larvae of many marine benthic invertebrates is either stimulated or inhibited by sediment-bound organic matter (reviewed by Gray 1974, Pawlik 1992, Snelgrove \& Butman 1994, Hadfield \& Paul 2001). For example, Grassle et al. (1992) demonstrated that sediment organic matter probably serves as a larval settlement triggering cue for Capitella sp. I (i.e. larvae preferentially settle in organic-rich rather than in organic-poor sediments). Subsequent studies have correlated the larval settlement of this species with sediment organic matter (Cohen \& Pechenik 1999, Thiyagarajan et al. 2005). Sediment organic matter not only influences the pre-settlement process, it also plays a key role in determining post-settlement performance (e.g. Forbes \& Lopez 1990, Tsytsynum et al. 1990, Bridges et al. 1994, Qian 1994, Linton \& Taghon 2000). It is widely believed that Capitella sp. I grows and reproduces faster in areas where sediments contain a higher concentration of enzymatically hydrolyzable amino acids (EHAA) than the threshold level (Hu et al. 2003). The distribution of species and consequently the species composition in a community, thus, are at least partly determined by the species relationship to sedimentary biochemical properties, especially organic matter composition, habitat preference of larvae with respect to those biochemical properties, and the subsequent growth response of juveniles in that habitat. In the literature, however, there are only a few studies which have examined the relationship between larval habitat selection and post-settlement performance (e.g. Stoner et al. 1996). As pointed out by Marinelli \& Woodin (2004), so far only one study has tested the hypothesis that habitat choice made by Capitella sp. I larvae is directly related to the nutritional quality of a habitat that supports higher postsettlement performance (Cohen \& Pechenik 1999).

The quantity and composition of the sediment organic matter in shallow coastal waters may vary at different spatial and temporal scales due to physicochemical processes occurring in the overlying water layers (e.g. Hung et al. 2000). These spatio-temporal changes in the sediment may substantially affect larval metamorphosis at small spatial scales. In addition, these biochemical changes may also alter the nutritional value of the sediment for deposit-feeding polychaetes (see Gremare et al. 1997, Rossi \& Lardicci 2002) and consequently juvenile performance. However, very little is known about spatio-temporal variations in the biochemical composition of sediment organic matter (Fabiano et al. 1995, Pusceddu et al. 1999), especially in subtropical areas. Furthermore, no studies have been carried out to link spatio-temporal variation in the biochemical properties of sediments to larval habitat selection and juvenile growth, although such knowledge is important in understanding the link between the environment, sediment characteristics, larval ecology and population dynamics of deposit feeding polychaetes.

In a previous paper we reported the relationship between spatial changes in the biochemical properties of the sediment in subtropical Hong Kong waters and larval habitat selection by Capitella sp. I (Thiayagarajan et al. 2005). To further explore the relationship between larval habitat selection and sediment biochemical properties, we here examined the influence of spatio-temporal variation in biochemical properties of soft sediments on both the larval habitat selection and juvenile performance of Capitella sp. I. Specifically, sediments from 5 sites in contrasting environments were sampled quarterly in both the wet and dry seasons in order to study the influence of the organic matter quantity and composition on larval habitat selection. Additional experiments were conducted to test the hypothesis that protein and lipid enrichment enhance the attractiveness of sediment to settling larvae. The performance of juveniles (both growth and survivorship) in sediments of varying biochemical properties was also examined in order to determine the ability of Capitella sp. I larvae to predict a site suitable for adults.

\section{MATERIALS AND METHODS}

Sediment collection site and procedure. The sediment samples for the present study were collected in a pollution gradient along Victoria Harbor, Hong Kong, SAR (Fig. 1). The hydrography in the study area varies at spatio-temporal scales (for details see Shin \& Ellingsen 2004). As a result of freshwater outflow from the Pearl River on the western side of Victoria Harbor, an increasing trend in salinity concentration from west to east occurs during summer (May to September). In winter, the Kuroshio Current (high salinity and temperature) affects the hydrography in this region. In addition to these natural events, negative human impacts due to pollution and sewage discharge are serious in the study area (see Wong et al. 2000). Therefore, this area was chosen for an investigation of spatio-temporal variation in soft-bottom biochemical characteristics in a heterogeneous marine environment and their consequent influence on larval metamorphosis and juvenile performance under laboratory conditions.

Sediment samples from 5 sites along Victoria Harbor were used in this study. These sites are hereafter referred to as PC (Peng Chau), VHW (Victoria Harbor west), VH (Victoria Harbor), VHE (Victoria Harbor east), and TLC (Tung Lung Chau) (Fig. 1) and all these sites are located at relatively stable depths (10 to $15 \mathrm{~m}$ ). The westernmost site (PC) is heavily affected by the 


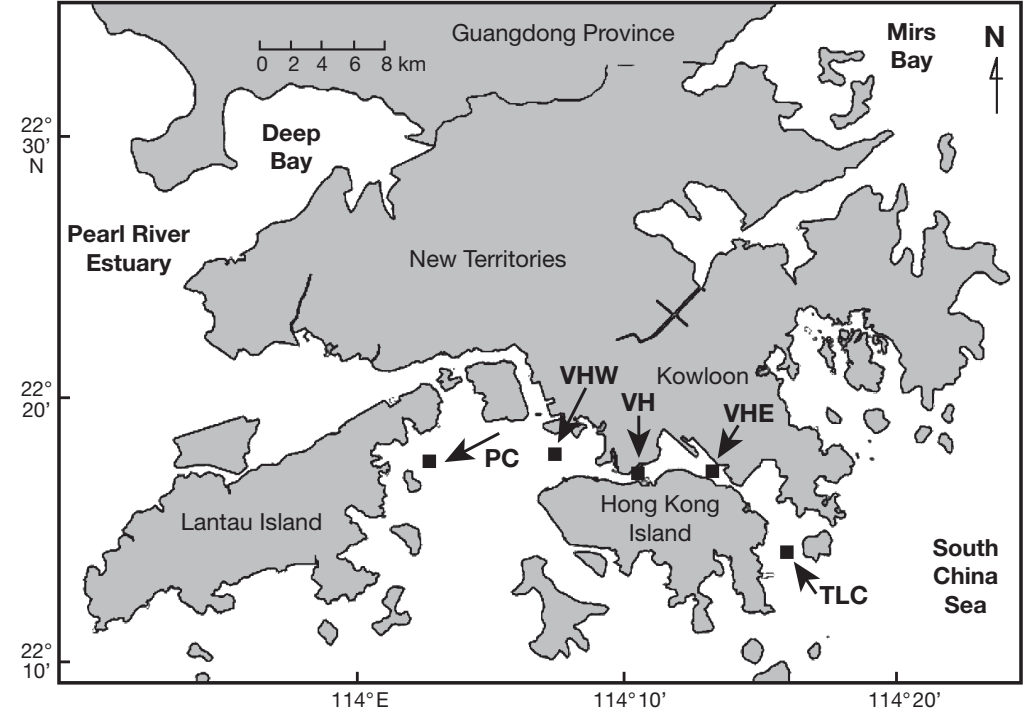

Fig. 1. Location of sediment collection sites in Victoria Harbor, Hong Kong. PC: Peng Chau; VHW: Victoria Harbor west; VH: Victoria Harbor; VHE: Victoria Harbor east; TLC: Tung Lung Chau

discharge from the Pearl River and the easternmost site (TLC) is oceanic. The transition sites, VHW, VH, and VHE are polluted by domestic sewage (raw or primarily treated) discharges from some 3.5 million people (Wong et al. 2000). Samples were collected on 4 sampling dates: 13 August 2004, 14 December 2004, 17 March 2005 and 12 June 2005. On each sampling date hydrographic data were collected, but will be presented elsewhere. To obtain surface muds of more or less similar grain size, extra care was taken in selecting the precise sampling locations within each site. Three homogenized surface sediment samples (from the top $2 \mathrm{~cm}$ ) per site and sampling date were collected using a van Veen grab $\left(0.1 \mathrm{~m}^{2}\right)$. For biochemical analysis and juvenile performance experiments, sediment samples were frozen $\left(-20^{\circ} \mathrm{C}\right)$ until used. Chlorophyll a (chl a) content was determined immediately after sample collection. For the larval settlement bioassay, fresh samples kept at $4^{\circ} \mathrm{C}$ were used within $7 \mathrm{~d}$.

Biochemical analysis of sediments. The physical properties of the sediments were determined in terms of their mean grain size and percent water content (complete data were not shown in the present paper since there was no site $\times$ sampling date interaction). Total organic carbon (TOC) and nitrogen (TN) were used to quantify the organic matter content. Chl a concentration was used as a proxy of microalgal biomass. The biopolymeric carbon (BPC, i.e. sum of proteins, carbohydrates and lipids) and EHAA concentrations were used to estimate sediment organic matter composition or nutritional value.

TOC and TN were determined after acidification using a CHNS Perkin Elmer 2400 elemental analyzer.
Chl a was measured fluorometrically (Loftis \& Carpenter 1971). Total carbohydrates were measured using the phenolsulphuric acid method (Underwood et al. 1995). Proteins and lipids were measured according to Hartree (1972) and Marsh \& Weinstein (1966), respectively. Carbohydrate, protein, and lipid concentrations were converted to carbon equivalents using the conversion factors $0.45,0.49$ and 0.75, respectively (Fabiano et al. 1995). EHAA was measured according to Mayer et al. (1995). For all biochemical analysis, sediments that had been treated in the muffle furnace $\left(550^{\circ} \mathrm{C}\right.$ for $\left.6 \mathrm{~h}\right)$ were used as blanks. For each biochemical analysis, 180 samples (3 subsamples $\times 3$ replicates $\times$ 5 sites $\times 4$ sampling dates) were used.

Study organism and larval collection. Procedures for the adult maintenance and larval collection of the study organism (Capitella sp. I) were described in detail in Thiyagarajan et al. (2005). Briefly, brooding females (along with their tubes) were isolated in clean dishes and the larvae obtained were transferred into filtered seawater in order to prevent their metamorphosis (Cohen \& Pechenik 1999). Larvae obtained from several broods (usually from 10 to 20) were combined and used for the experiments within $24 \mathrm{~h}$ (Butman \& Grassle 1992).

Expt 1. Influence of spatio-temporal variation in biochemical properties of sediments on larval habitat selection. The main goal of this experiment was to determine the larval preference of Capitella sp. I with respect to sediments with varying biochemical properties. Larval settlement choice (or habitat selection) of 5 sediment treatments (corresponding to 5 sites) collected on each sampling date was tested according to the method of Grassle et al. (1992) in still water multiple-choice plexiglass chambers $(10 \times 10 \times 2 \mathrm{~cm})$. Each chamber accommodated a total of $25(5 \times 5)$ $1.2 \mathrm{~cm}$ diameter by $0.3 \mathrm{~cm}$ deep cylindrical compartments made of plexiglass. These compartments were arranged in 5 rows and columns and separated by $0.5 \mathrm{~cm}$ partitions. There were 5 compartment-replicate per sediment treatment in each chamber. The sediment samples were placed in the chamber according to an orthogonal Latin-square design. After adding the sediments, chambers were filled with $100 \mathrm{ml}$ of $0.22 \mu \mathrm{m}$ filtered seawater (34\%o) (FSW) and subsequently a known number of larvae ( 200 to 500) were transferred into the chamber and incubated at $24^{\circ} \mathrm{C}$ in darkness. The number of newly metamorphosed larvae in each compartment was counted after $24 \mathrm{~h}$. The experiment was repeated 3 times using lar- 
vae obtained from different broods. There were 3 chambers in each repeat serving as 3 replicates. In total, 36 chambers (4 sampling dates $\times 3$ repeats $\times$ 3 replicates) were used in this experiment. During each sampling date, larval habitat selection response showed similar trend among the 3 repeats; therefore, only the first repeat data were shown in this paper. For each sampling date, effects of row, column, site (fixed factors) and replicate (random factor) on the numbers of metamorphosed larvae were analysed with a replicated Latin-square ANOVA (Grassle et al. 1992). Since the effects of row, column, and site on larval metamorphosis were not consistent among replicate chambers, the number of metamorphosed larvae per sediment treatment in each replicate chamber was analysed separately using a 1-way Latin-square ANOVA. If the site effect was significant, Tukey's multiple comparison tests were used to determine differences among sites in each replicate chamber.

Expt 2. Larval preference for sediments with different proportions of attractive and unattractive muds. This experiment set out to test whether larvae could choose sediment treatments differing in proportions of attractive and unattractive muds. We tested larval settlement preference in the following 5 treatments: 100, $75,50,25$ and $0 \%$ of attractive mud obtained by mixing unattractive mud (PC mud from June 2005 cruise) with different amounts of attractive mud ( $\mathrm{VH}$ mud from June 2005 cruise). Larval settlement choice of these 5 sediment treatments was tested in a still water multiple-choice chamber as described in Expt 1.

Expt 3. Larval preference with respect to unattractive PC mud: effect of protein, lipid and carbohydrate enrichment. The results obtained in Expt 1 indicated that Capitella sp. I larvae did not show a clear preference for sediments collected at PC over other sites (e.g. $\mathrm{VH}$ mud) regardless of sampling dates. This experiment was therefore designed to evaluate whether larval preference for PC mud would be triggered by either protein (Expt 3A), lipid (Expt 3B) or carbohydrate (Expt 3C) enrichment. Bovine serum albumin (BSA), tripalmitin and glucose were used to enrich proteins, lipids and carbohydrates in PC sediment, respectively. BSA and glucose were dissolved in seawater and mixed with sediment to obtain the desired enrichment levels, whereas tripalmitin was dissolved in 2:1 chloroform: methanol. In Expt 3A, larvae were offered 4 choices: Neg (PC mud, which served as the negative control), Neg_0.1 (PC mud enriched with $0.1 \mathrm{mg} \mathrm{BSA} \mathrm{g}^{-1} \mathrm{DW}$ ): Neg_1 (PC mud enriched with $1 \mathrm{mg} \mathrm{BSA} \mathrm{g}^{-1} \mathrm{DW}$ ) and Pos (VH mud, which served as the positive control). In Expt 3B, larvae were offered 4 choices: 1Neg (PC mud, which served as the first negative control), 2Neg (PC mud enriched with solvents, which served as the second negative control), Neg_1 (PC mud enriched with
$1 \mathrm{mg}$ tripalmitin $\mathrm{g}^{-1} \mathrm{DW}$ ) and Pos (VH mud, which served as the positive control). In Expt 3C, larvae were offered Neg, Neg_0.1 (PC mud enriched with $0.1 \mathrm{mg}$ glucose $\left.\mathrm{g}^{-1} \mathrm{DW}\right)$, Neg_1 (PC mud enriched with $1 \mathrm{mg}$ glucose $\mathrm{g}^{-1} \mathrm{DW}$ ) and Pos (VH mud, which served as the positive control). A larval settlement choice assay was run in a still water multiple-choice chamber. This experiment was designed as a replicated $4 \times 4$ Latinsquare and run as described in Expt 1.

Expt 4. Influence of spatio-temporal variation in biochemical properties of sediment on juvenile performance. In this experiment the vulnerability of newly metamorphosed larvae to spatio-temporal variations in sediment biochemical properties was evaluated under laboratory conditions. We used newly metamorphosed larvae (i.e. $24 \mathrm{~h}$ old early juveniles) because they were likely to grow quickly and allowed us to compare changes in growth with respect to sediment treatments among juveniles that originated from the same batch of larvae. Early juveniles were obtained according to the methods of Tsutsumi et al. (2001). Briefly, larvae obtained from several broods (i.e. 10 to 20) were combined and transferred to a dish containing fine sediment and FSW. After $30 \mathrm{~min}$, all the unsettled larvae were discarded and juveniles were held in the same dish until used for the growth experiment (ca. $24 \mathrm{~h}$ later).

Sediment samples used in Expt 1 were also used in Expt 4. Unlike in Expt 1, samples were frozen at $-20^{\circ} \mathrm{C}$ until used in August to September 2005. In total, 180 sediment samples were used ( 3 subsamples $\times 3$ replicates $\times 4$ sampling dates $\times 5$ sites). Samples were sieved to $125 \mu \mathrm{m}$ to ensure that most of the particles were within the ingestible size range for Capitella sp. I (Foss \& Forbes 1997). Wet sediment sample (15 g) was added to $25 \mathrm{ml}$ plastic containers, which were then filled with FSW. A total of 25 early juveniles were added to each container. The water temperature during the entire experimental period was maintained at $24 \pm 2^{\circ} \mathrm{C}$ under continuous darkness. Containers were gently aerated via tubes with plastic pipette tips suspended $1 \mathrm{~cm}$ below the water surface. Three-quarters of the water in each container was replaced every other day. At the end of the experiment (10 d), all survivors were counted and growth was determined. Body volume was used as a measure of juvenile growth (Foss \& Forbes 1997). The worms were videotaped and the total length and width of the individuals measured. The body volume of each individual was calculated using the equation $V=\pi(D / 2)^{2} L$, where $D$ and $L$ represent the diameter (width) and length of each worm. To determine the percentage of survival, we counted the number of living juveniles in each sample, divided by the total number of juveniles added, and multiplied by 100. The worms were not fed during the experiment. 
We used a 2-way ANOVA with sampling site and date as the fixed factors to compare changes in juvenile growth and survival with respect to different sediment treatments. Data were further analysed using 1-way ANOVA followed by Tukey's multiple comparison test to determine the effect of sampling site on juvenile performance at fixed levels of sampling date, and vice versa.

Spatial distribution pattern of Capitella spp. The objective of this experiment was to compare larval preferences with respect to the sediment biochemical properties revealed in our laboratory findings with the actual distribution and abundance of Capitella spp. in the field. The spatial distribution of Capitella spp. in the study area was estimated by taking replicate samples $(\mathrm{n}=4)$ with a $0.1 \mathrm{~m}^{2}$ van Veen grab at 5 sites (see Fig. 1) in August 2004 and again in December 2004. Samples were sieved on a $0.5 \mathrm{~mm}$ sieve, and the retained fauna was fixed in $5 \%$ boraxbuffered formalin and stained with $1 \%$ Rose Bengal for later identification of Capitella spp. One-way ANOVA and Tukey's multiple comparison tests were used to test differences in Capitella spp. abundance among sites (spatial differences) at each sampling date.

\section{RESULTS}

\section{Spatio-temporal variation in sediment biochemical properties}

Most of the sediment samples used in this study were muddy (mean grain size ranged from 45 to $65 \mu \mathrm{m}$ ) with 49 to $65 \%$ water content and were not different markedly among 5 sites (Table 1). However, a 2-way ANOVA analysis revealed that all 5 biochemical sediment parameters measured, TOC, TN, chl $a, B P C$ and EHAA, were significantly different among sites and sampling dates and there was a significant interaction between these 2 factors (Table 2).
The minimum TOC content was recorded at PC $(\sim 0.7 \%)$ and the maximum was recorded at VHE and $\mathrm{VH}(\sim 2 \%)$ in June 2005 (Fig. 2A). On all 4 sampling dates, TOC at PC and VHW was significantly lower than that at VH. However, there was no clear temporal pattern. The TN content varied from $\sim 0.07$ to $0.4 \%$ and showed seasonality that was characterised by slightly higher values in August 2004 than on other sampling dates at each site (Fig. 2B). Noticeably, PC had consistently lower TN values than $\mathrm{VH}, \mathrm{VHE}$ and VHW (except in August 2004). The chl a values exhibited clear seasonality, with the highest values in June 2005 followed by March 2005, August 2004 and December 2004 (Fig. 2C).

Concentrations of the 2 main biochemical components that describe the nutritional quality of organic matter (i.e. BPC and EHAA) are shown in Fig. 3. Generally, the BPC displayed the highest values at TLC, $\mathrm{VHE}$ and $\mathrm{VH}$. The BPC values were in fact significantly lower at both PC and VHW than at other sites (except in December 2004, when TLC had similar values to PC and VHW) (Fig. 3A). The EHAA ranged between $0.01 \mathrm{mg} \mathrm{g}^{-1} \mathrm{DW}$ at PC in June 2005 and $0.31 \mathrm{mg} \mathrm{g}^{-1} \mathrm{DW}$ at $\mathrm{VH}$ in June 2005 (Fig. 3B). The EHAA concentration of PC sediments was significantly lower than that of other sites on all 4 sampling dates except in December 2004, when it was not significantly different from VHW. There was no clear seasonality,

Table 2. Summary of 2-way ANOVA results of total organic carbon (TOC), nitrogen (TN), chlorophyll a (chl a), biopolymeric carbon (BPC) and enzymatically hydrolizable amino acid (EHAA) data obtained from 4 sampling dates (13 August 2004 , 14 December 2004, 17 March 2005 and 12 June 2005). There were 5 sites (TLC, VHE, VH, VHW and PC: for site abbreviations see Fig. 1) per sampling date. Data were square-root transformed to meet ANOVA assumptions. ${ }^{*} p<0.05,{ }^{* *} p<0.01,{ }^{* * *} p<0.001$

\begin{tabular}{|c|c|c|c|c|c|c|c|c|c|c|c|}
\hline \multirow[t]{2}{*}{ Source } & \multirow{2}{*}{ df } & \multicolumn{2}{|c|}{ TOC } & \multicolumn{2}{|r|}{ TN } & \multicolumn{2}{|c|}{ Chl a } & \multicolumn{2}{|c|}{$\mathrm{BPC}$} & \multicolumn{2}{|c|}{ EHAA } \\
\hline & & MS & $F$ & MS & $F$ & MS & $F$ & MS & $F$ & MS & $F$ \\
\hline Site & 4 & 0.093 & $18.651^{* * *}$ & 0.039 & $31.057^{* * *}$ & 0.001 & $7.001^{* * *}$ & 0.617 & $12.868^{* * *}$ & 0.094 & $25.041^{* * *}$ \\
\hline Sampling date & 3 & 4.651 & $926.303^{* * *}$ & 0.055 & $43.771^{* * *}$ & 0.017 & $70.217^{* * *}$ & 33.138 & $691.606^{* * *}$ & 0.002 & $0.568^{* * *}$ \\
\hline Site $\times$ Date & 12 & 0.018 & $3.561^{* *}$ & 0.007 & $5.861^{* *}$ & 0.001 & $2.053^{*}$ & 0.422 & $8.807^{* * *}$ & 0.018 & $4.912^{* * *}$ \\
\hline Error & 80 & 0.005 & & 0.001 & & 0.001 & & 0.004 & & 0.003 & \\
\hline
\end{tabular}



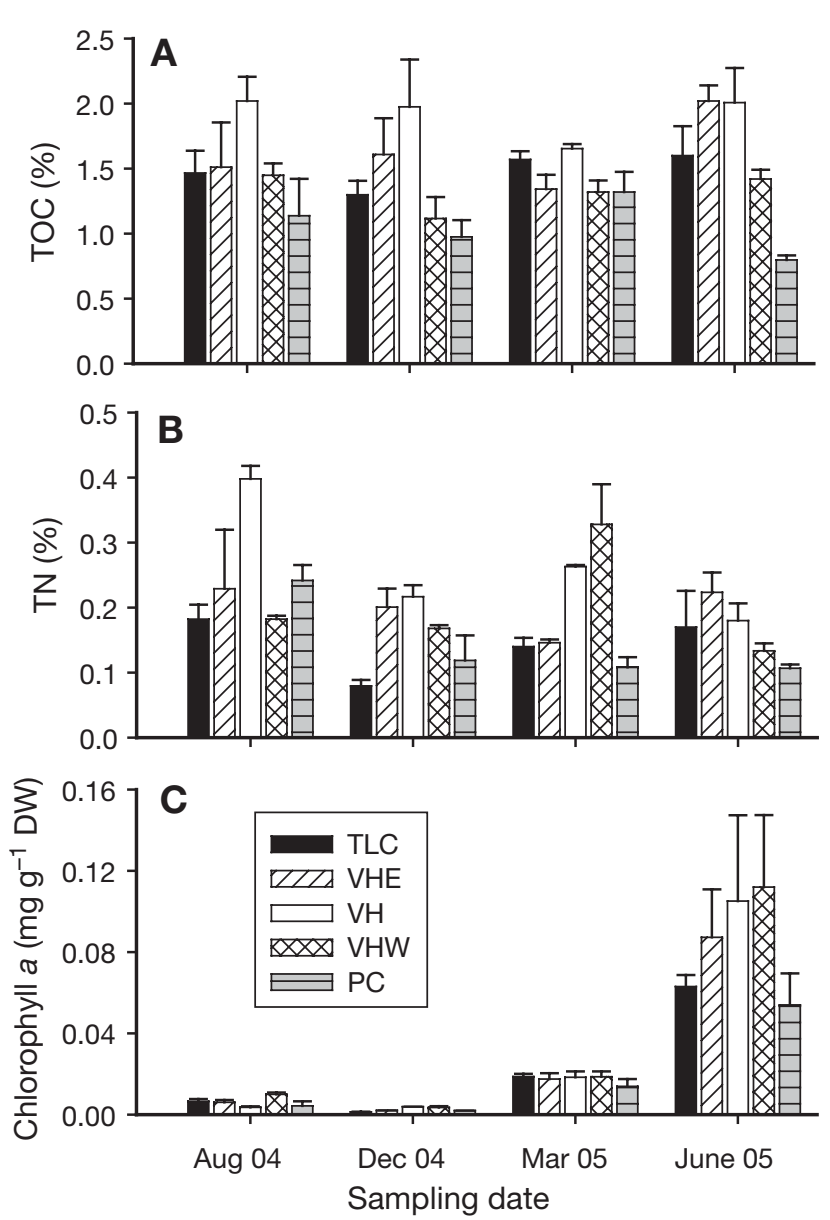

Fig. 2. Sediment biochemical properties (quantitative measures of organic matter) in the study area. (A) Total organic carbon (TOC); (B) total nitrogen (TN); and (C) chlorophyll a concentration. Results presented as the mean \pm SD of 3 replicates. Each replicate is the mean of 3 subsamples. See Fig. 1 for site abbreviations

but the PC sediments in June 2005 had significantly lower values than those of the other 3 sampling dates (Fig. 3B). Thus, sediment samples collected in our study covered a wide range of organic matter quantity and composition and, therefore, were suitable for the investigation of possible relationships among sediment biochemical properties, larval habitat selection behavior and subsequent juvenile performance.

\section{Larval habitat selection (Expt 1)}

The actual mean number of metamorphosed larvae (juveniles) in each sediment treatment and bioassay chamber is shown in Fig. 4. Statistical analysis of data showed that the number of metamorphosed larvae differed significantly with respect to site and sampling date (Table 3). There was a strong interaction between these 2 factors. Although larval metamorphosis in all
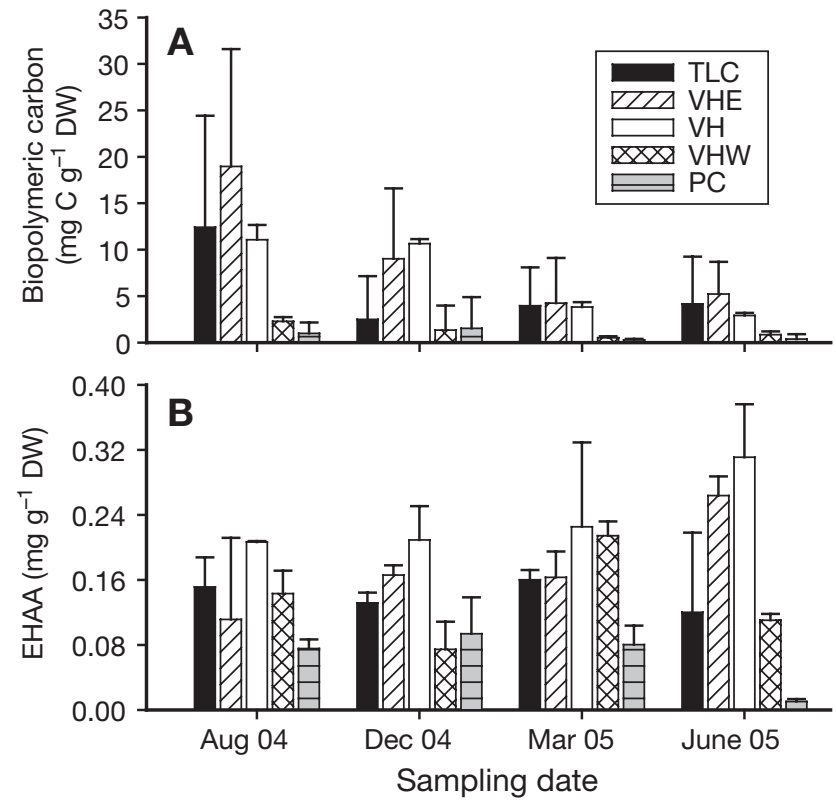

Fig. 3. Sediment biochemical properties (qualitative measures of organic matter) in the study area. (A) Biopolymeric carbon; (B) enzymatically hydrolysable amino acid (EHAA) concentration. Results presented as the mean \pm SD of the 3 replicates. Each replicate is the mean of 3 subsamples. See Fig. 1 for site abbreviations

replicate chambers on each sampling date followed a similar trend (see Table 3), differences in larval metamorphosis within each chamber were analysed using 1-way Latin-square ANOVA. No significant row-column effects were found in this experiment, suggesting a good experimental precision and uniform sediment treatment response by larvae (data not shown in Table 3). In August 2004, larval metamorphosis was consistently lower at PC than at other sites (Fig. 4A-C). However, there was no significant difference in larval

Table 3. Three-way nested Latin-square ANOVA showing the effect of sampling date (fixed factor; 4 levels: 13 August 2004, 14 December 2004, 17 March 2005 and 12 June 2005), replicate larval bioassay chamber (random factor, nested with date; 3 levels: Replicates 1,2, and 3) and site (fixed factor; 5 levels: TLC, VHE, VH, VHW and $\mathrm{PC}_{\text {; }}$ for site abbreviations see Fig. 1) on larval habitat selection. Data were $\log (x+1)$ transformed to meet ANOVA assumptions. Significant values shown in bold. In most cases, no significant row or column effect was observed in the larval metamorphosis in each bioassay chamber. Therefore these 2 factors were not included in the analysis

\begin{tabular}{|lrccr|}
\hline Source & df & MS & $F$ & \multicolumn{1}{c|}{ p } \\
\hline Site & 4 & 7.325 & 86.479 & $<\mathbf{0 . 0 0 1}$ \\
Sampling date & 3 & 0.385 & 4.544 & $<\mathbf{0 . 0 0 5}$ \\
Replicate (date) & 8 & 0.142 & 1.679 & 0.101 \\
Site $\times$ Date & 12 & 0.666 & 6.619 & $<\mathbf{0 . 0 0 1}$ \\
Error & 284 & 0.084 & & \\
\hline
\end{tabular}



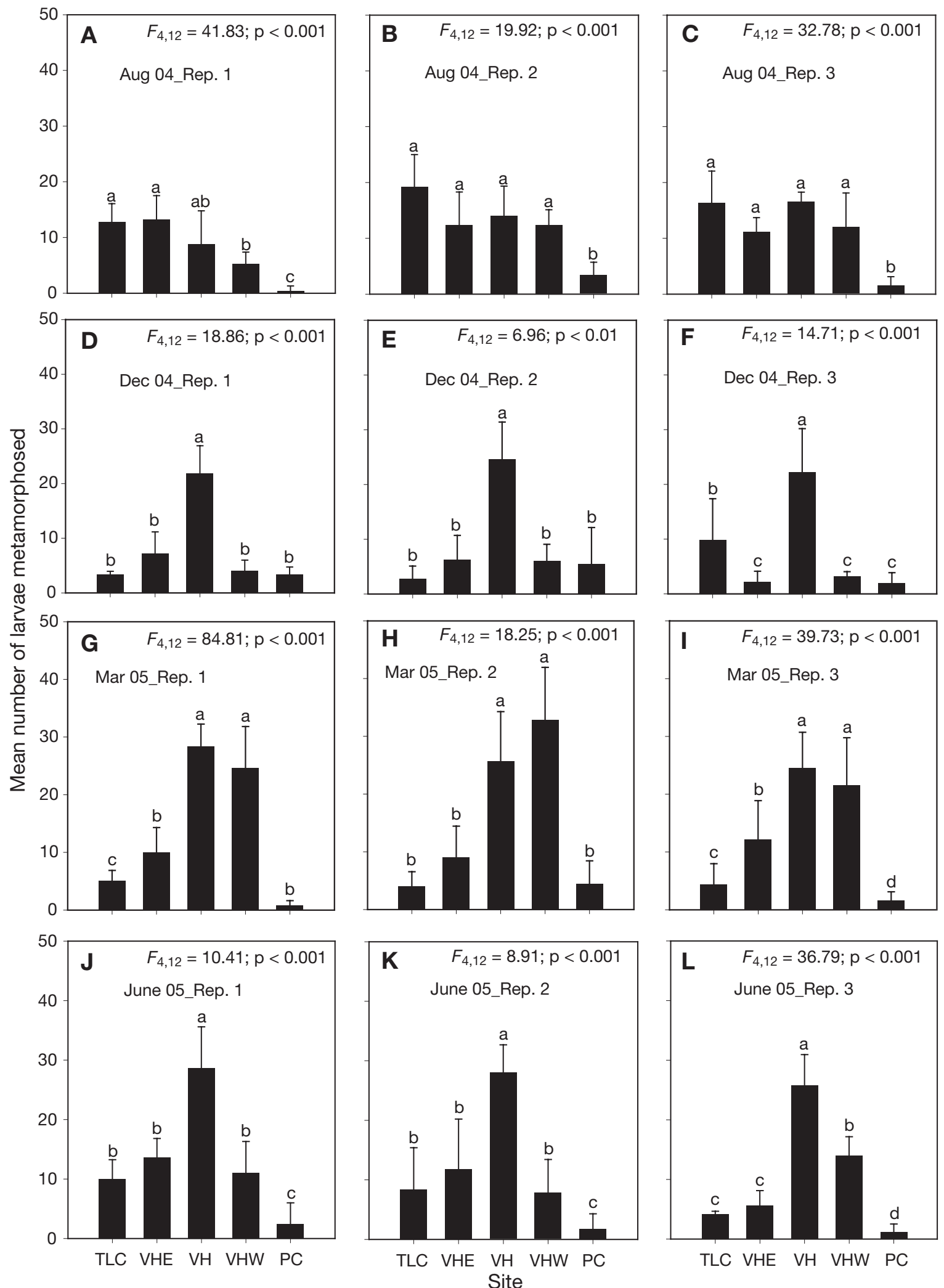

Fig. 4. Expt 1. Larval metamorphosis in August 2004 (A to C: Replicates 1 to 3, respectively), December 2004 (D to F), March 2005 (G to I) and June 2005 ( $\mathrm{J}$ to L). Results presented as the mean $\pm \mathrm{SD}$ of the 5 compartment-replicates. Results of the Latin-square ANOVA shown at top of each figure. Mean values that are significantly different according to Tukey's HSD tests indicated by different letters above the bar. See Fig. 1 for site abbreviations 
metamorphosis among TLC, VHE, VH and VHW. An exception was Replicate 1 (Fig. 4A), where larval metamorphosis was significantly reduced at VHW compared to the other 3 sites. In both December 2004 and June 2005, significantly more larvae metamorphosed at $\mathrm{VH}$ than at other sites (Fig. 4D-F, J-L). Interestingly, in March 2005, significantly more larvae metamorphosed at both VH and VHW than at the other 3 sites (Fig. 4G-I). Once again, only a few larvae metamorphosed at PC as compared to the other sites in June 2005. Thus, this experiment clearly demonstrated that larvae did not prefer PC mud, irrespective of sampling dates. Also, larval preference for sediment samples collected from particular sites varied with respect to sampling dates.

\section{Larval habitat selection (Expts 2 and 3)}

In Expts 2 and 3, sediment treatments had significant effects on larval metamorphosis (Table 4). Unlike in Expt 1, larval metamorphosis followed a similar pattern in all 3 replicate bioassay chambers within each experiment. There was significantly higher and lower larval metamorphosis in positive $(100 \%$ attractive mud) and in negative ( $0 \%$ attractive mud) controls, respectively. Larval metamorphosis increased with an increasing concentration of attractive mud or decreasing concentration of unattractive mud (Fig. 5A-C; Table 4). In Expt 3A, the larval metamorphosis in both positive control and the highest protein treatment (Neg_1) was significantly higher than those in the negative control and the lowest protein treatment (Neg_0.1) (Fig. 5D-F). In Expt 3B, a significantly higher number of larvae metamorphosed in lipid treatment (Neg_1) than those in positive control and the 2 negative controls (i.e. Neg and $1 \mathrm{Neg}$ were prepared using seawater and solvent, respectively) (Fig. 5G-I). In contrast, in Expt 3C, carbohydrate treatments did not enhance larval metamorphosis compared to Neg, but the values were significantly lower than those in the positive control (Fig. 5J-L).

\section{Relationship between sediment biochemical properties and larval habitat selection}

Larval metamorphosis data in Expt 1 were used to measure the relationship between sediment biochemical properties and larval metamorphosis. In sediments, TOC, TN and EHAA concentrations demonstrated a positive influence on larval metamorphosis (Spearman's rank-correlation tests, $\mathrm{r}_{\mathrm{S}}=0.67$, 0.59 and 0.72 for TOC, TN and EHAA, respectively; $\mathrm{n}=20, \mathrm{p}<0.05)$. On the other hand, sediment chl $a$ and BPC contents did not have significant relationship with larval metamorphosis $\left(\mathrm{r}_{\mathrm{S}}\right.$ $=0.21$, and 0.31 for chl $a$ and BPC, respectively; $\mathrm{n}=20, \mathrm{p}>0.05$ ).

\section{Juvenile performance (Expt 4)}

Fig. 6 shows the mean percent mortality and final body volume of juvenile Capitella sp. I after $10 \mathrm{~d}$ post-settlement in sediment samples collected from 5 sites on 4 sampling dates. Both juvenile mortality and body growth differed significantly among sampling sites and dates (Table 5). The interaction effect was significant. Between the 2 factors, sites caused a higher variation in both juvenile mortality and growth than sampling dates, as indicated by the MS values in Table 5. Irrespective of sampling dates, the percent mortality increased gradually from sediments collected in eastern (TLC) to western sites (PC), but only 

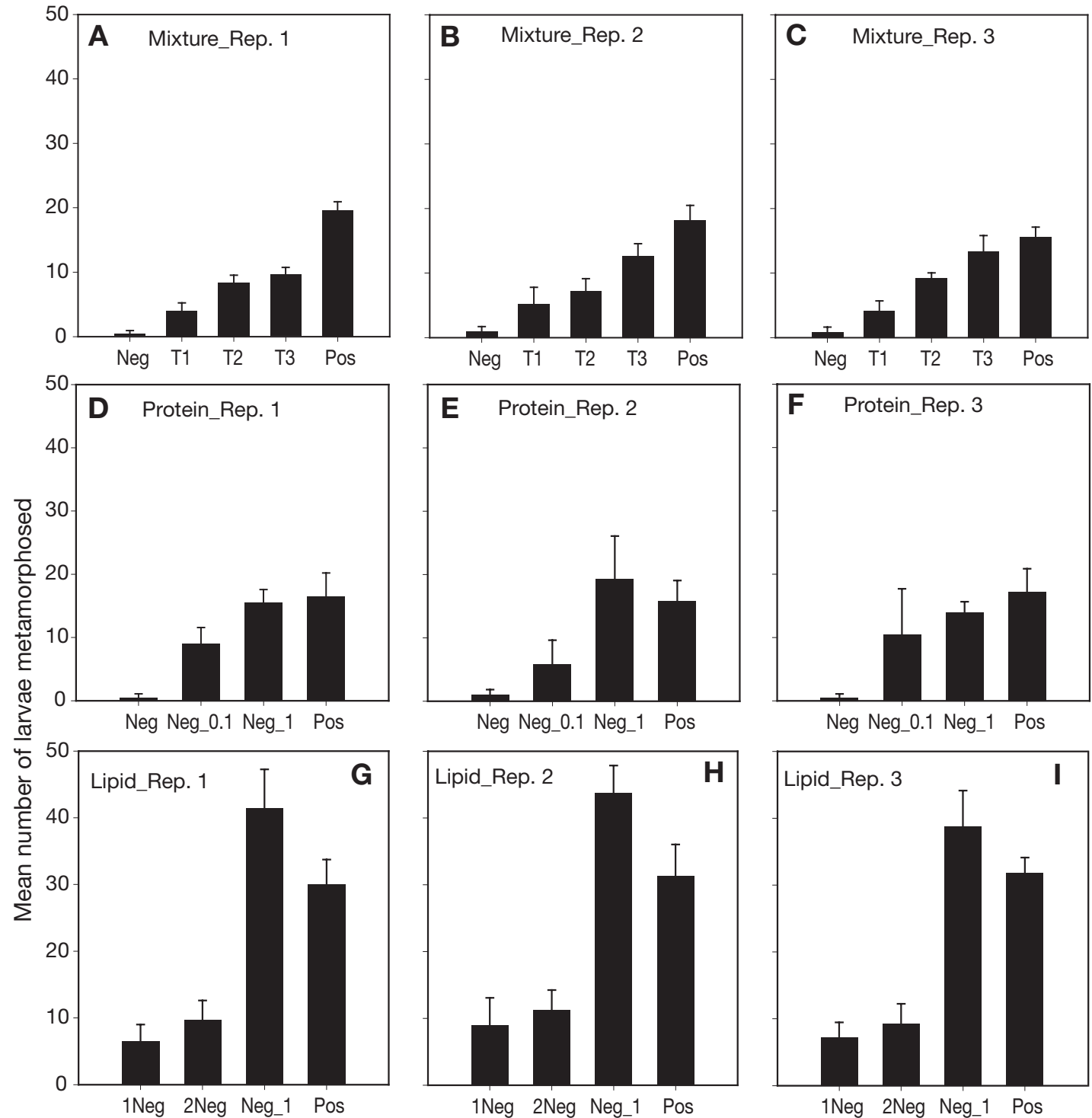

Neg Neg_0.1 Neg_1 Pos
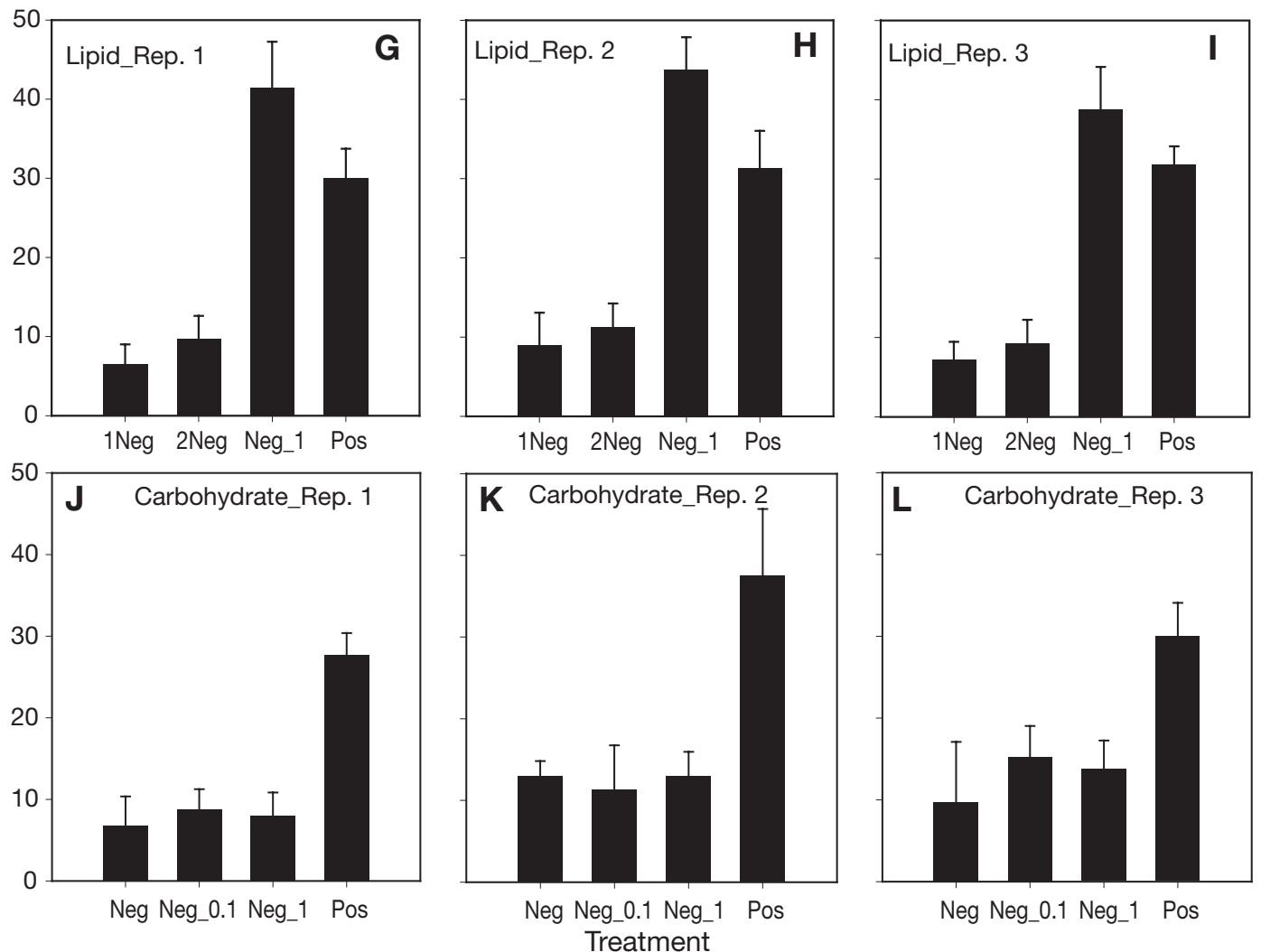

Fig. 5. Larval metamorphosis in Expts 2 and 3. (A to C) (Expt 2). Larvae had 5 choices: $0 \%$ (Neg, negative control), 25\% (T1, Treatment 1), $50 \%$ (T2, Treatment 2), $75 \%$ (T3, Treatment 3), and 100\% (Pos, positive control) attractive mud obtained by mixing unattractive mud (PC [Peng Chau] mud) with different amounts of attractive mud (VH [Victoria Harbor] mud). (D to F) (Expt 3A). Larvae were offered 4 choices: Neg (PC mud: negative control), Neg_0.1 (PC mud with 0.1 mg BSA g ${ }^{-1}$ DW), Neg_1 (PC mud with $1 \mathrm{mg} \mathrm{BSA} \mathrm{g}^{-1} \mathrm{DW}$ ) and Pos (VH mud: positive control). (G to H) (Expt 3B). Larvae were offered 4 choices: $1 \mathrm{Neg}$ (PC mud: first negative control), 2Neg (PC mud with solvent control), Neg_1 (PC mud with 1 mg tripalmitin $\mathrm{g}^{-1} \mathrm{DW}$ ) and Pos (positive control). (J to L) (Expt 3C). Larvae were offered 4 choices: Neg (PC mud: negative control), Neg_0.1 (PC mud with $0.1 \mathrm{mg} \mathrm{glucose} \mathrm{g}^{-1} \mathrm{DW}$ ), Neg_1 (PC mud with $1 \mathrm{mg}$ glucose $\mathrm{g}^{-1} \mathrm{DW}$ ) and Pos. Results presented as the mean \pm SD of the 5 compartment-replicates 

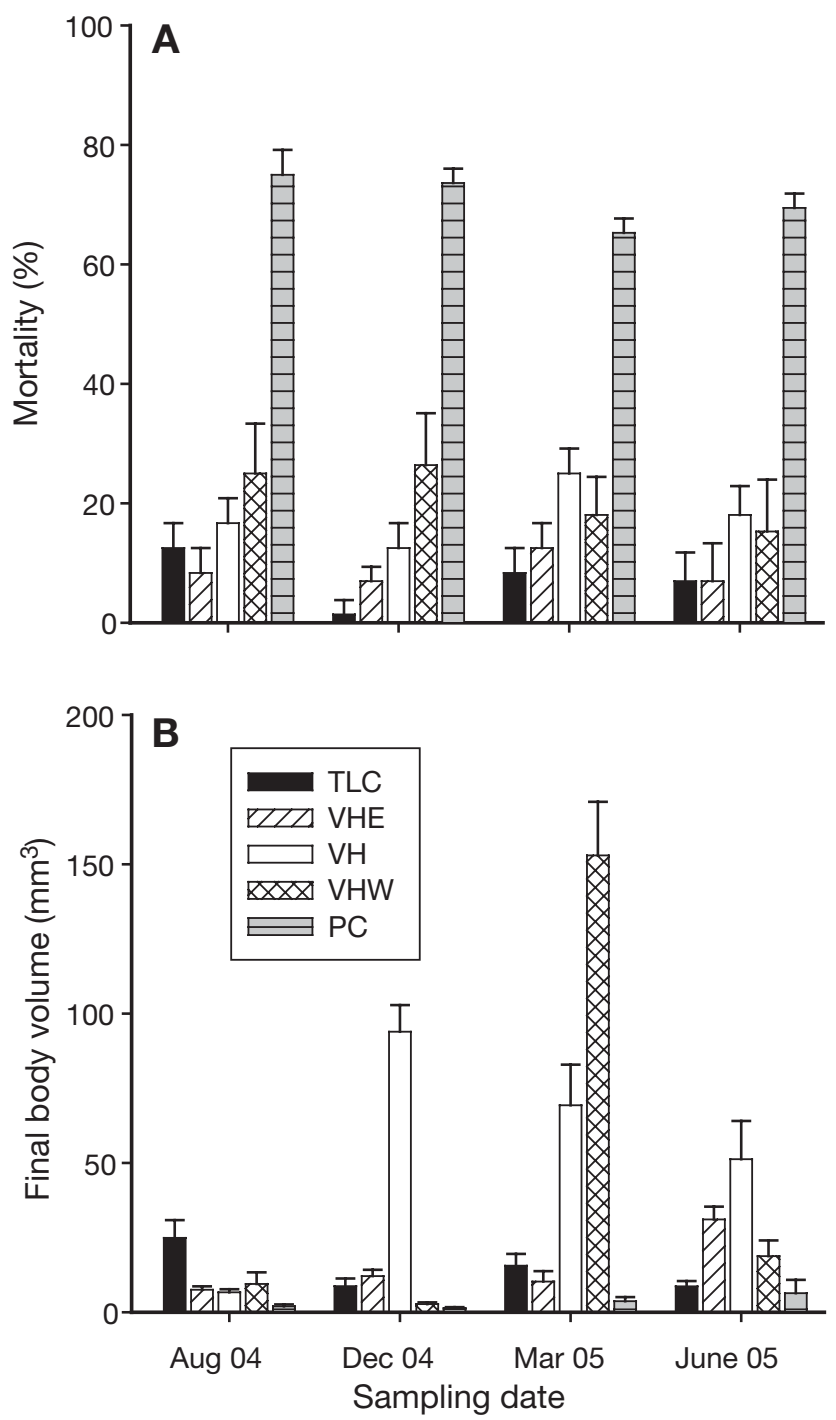

Fig. 6. Expt 4. (A) Juvenile mortality and (B) growth after $10 \mathrm{~d}$ post-settlement in sediment samples collected from 5 field sites (See Fig. 1 for site abbreviations) on 4 sampling dates (August 2004, December 2004, March 2005 and June 2005). Results presented as the mean \pm SD of 5 compartmentreplicates

Table 5. Two-way ANOVA showing the effect of site (fixed factor; 5 levels: TLC, VHE, VH, VHW and PC; for site abbreviations see Fig. 1), sampling date (fixed factor; 4 levels: August 2004, December 2004, March 2005 and June 2005) and their interaction on the juvenile mortality and growth. ${ }^{* *} \mathrm{p}<0.01$

\begin{tabular}{|lrrrrrr|}
\hline \multirow{2}{*}{ Source } & df & \multicolumn{3}{c}{ Juvenile mortality } & \multicolumn{2}{c|}{ Juvenile growth } \\
& & MS & \multicolumn{2}{c|}{$F$} & MS & \multicolumn{1}{c|}{$F$} \\
\hline Site & 4 & 75.825 & $236.123^{* *}$ & 87.795 & $544.228^{* *}$ \\
Sampling date & 3 & 38.185 & $118.909^{* *}$ & 30.254 & $187.54^{* *}$ \\
Site $\times$ Date & 12 & 5.545 & $17.259^{* *}$ & 22.036 & $136.598^{* *}$ \\
Error & 40 & 0.321 & & 0.161 & \\
& & & & & \\
\hline
\end{tabular}

the PC values were significantly higher than the other sites (see Fig. 6A, Table 6). At each of the sites tested, there was no obvious difference in percent juvenile mortality among sampling dates (Table 6).

Juvenile growth was significantly higher at TLC, VH, VHW and VH in August, December, March and June, respectively (Fig. 6B, Table 6). In August 2004 there was no difference in growth among VHW, VHE and VH. In December 2004 growth was significantly higher at VHE and TLC than at VHW and PC. Although the lowest growth was recorded at PC on all 4 sampling dates, the values were significant only in August 2004 and March 2005. At TLC, growth was significantly higher in August 2004 than on the other dates. Importantly, there was no significant difference in growth among the 4 sampling dates at PC (Table 6).

\section{Relationship between sediment biochemical properties and juvenile performance}

The sediment TOC and EHAA concentrations showed a significant negative $\left(\mathrm{r}_{\mathrm{S}}=-0.55\right.$, and -0.53 for TOC and EHAA, respectively; $\mathrm{n}=20, \mathrm{p}<0.05$ ) and positive $\left(\mathrm{r}_{\mathrm{S}}=0.51\right.$, and 0.72 for TOC and EHAA, respectively; $\mathrm{n}=20, \mathrm{p}<0.05$ ) relationship with juvenile mortality and growth, respectively. However, the relationship between sediment TN, chl $a$ and BPC concentrations and juvenile mortality or growth was not significant.

\section{Spatial distribution of Capitella spp.}

In August 2004 Capitella spp. was found at all sites except at PC (Fig. 7A). Both VH and VHW had similar densities that were significantly higher than at TLC. The lowest density was found at VHE. In December 2004 the highest density was found at VH, followed by TLC, VHW and VHE (Fig. 7B). The lowest density was found at PC.

\section{DISCUSSION}

\section{Sediment biochemical properties}

Considerable spatio-temporal heterogeneity of organic matter content and composition was clearly evident in the study area due to natural and anthropogenic activities in overlying waters and in the sediment itself. For example, the quantitative attributes of sediment organic matter such as TOC ranged from $\sim 0.7$ to $2 \%$, TN from $\sim 0.07$ to $0.4 \%$, and chl a from $\sim 0.01$ to $0.12 \mathrm{mg} \mathrm{g}^{-1} \mathrm{DW}$. Similarly, the qualitative attributes of sediment organic matter, liable BPC and 


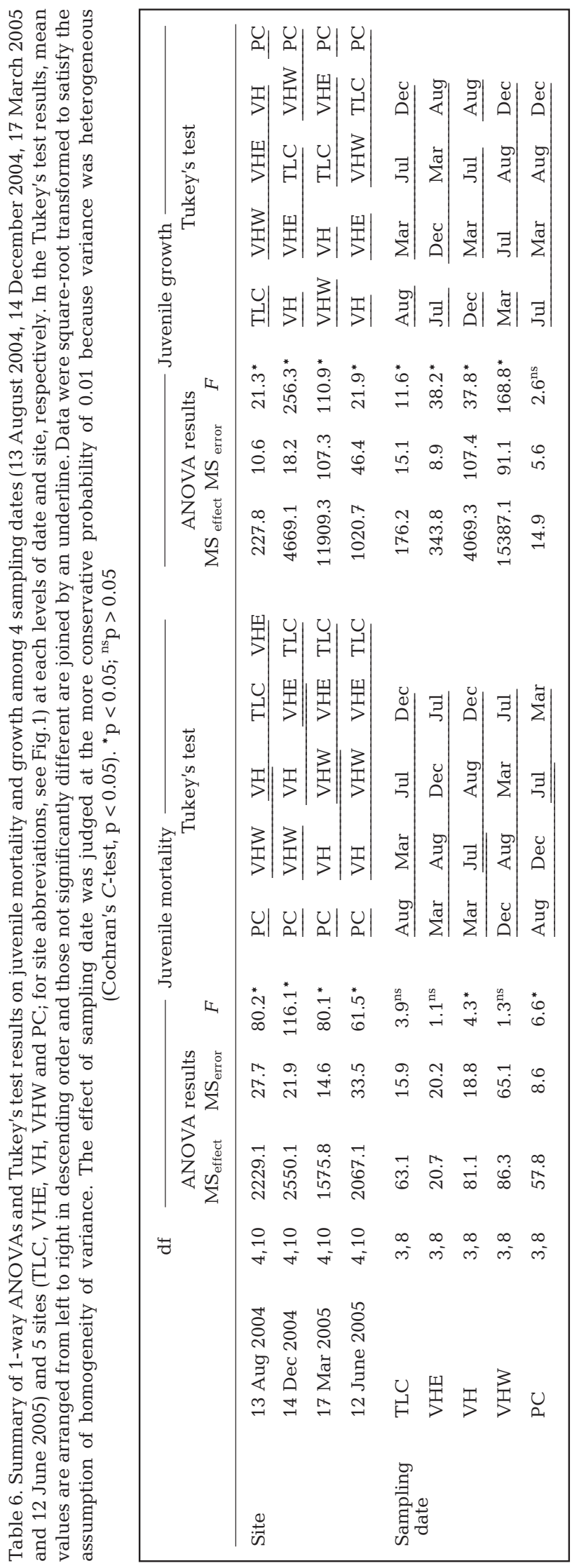

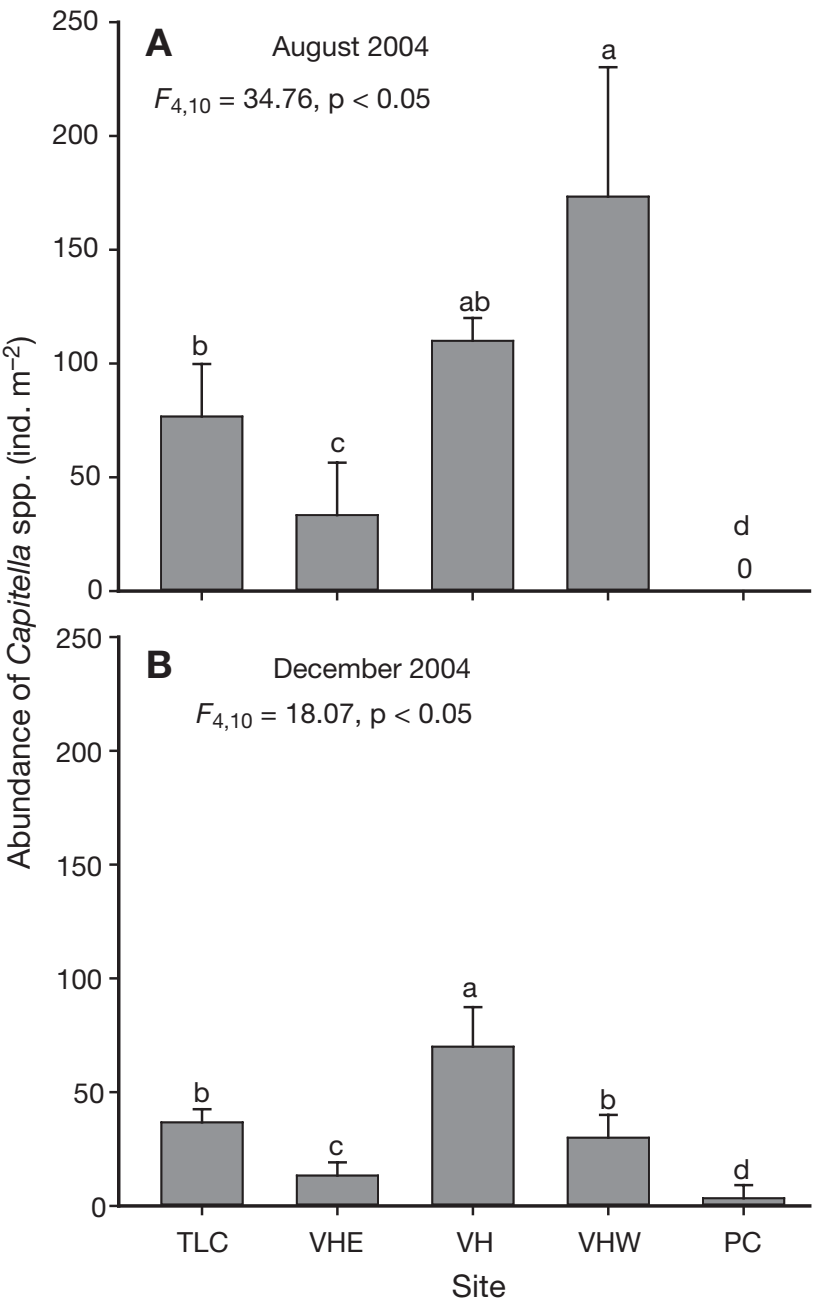

Fig. 7. Abundance of Capitella spp. at 5 field sites (see Fig. 1 for site abbreviations) in the study area during (A) August 2004 and (B) December 2004. Results presented as the mean $\pm \mathrm{SD}$ of 4 replicate samples. Results of ANOVA shown at the top of each figure. Mean values that are significantly different in Tukey's HSD tests indicated by different letters above the bar

EHAA concentrations, varied from $\sim 0.5$ to $18 \mathrm{mg} \mathrm{C} \mathrm{g}^{-1}$ DW and $\sim 0.01$ to $0.32 \mathrm{mg} \mathrm{g}^{-1} \mathrm{DW}$, respectively. Such large spatio-temporal variation in biochemical properties of surface sediment is not unusual in near shore benthic environments and has been reported previously from different shores (Fabiano et al. 1995 and references therein), but there has been no available information on the biochemical composition of organic matters in the study area, the vicinity of Victoria Harbor, Hong Kong. Therefore, the interesting part of our biochemical data was that significant spatio-temporal differences were not only reflected in the amount of organic matter (e.g. TOC and TN), but also in the nutritional quality or composition of organic matter (e.g. BPC and EHAA). The main aim of the present study 
was not to correlate the overlying water quality and the biochemical properties of sediments (which will be addressed elsewhere). Instead, we used these sediment samples to study the relationship between sediment biochemical properties, larval metamorphosis and juvenile performance in Capitella sp. I.

\section{Larval habitat selection}

A series of laboratory experiments conducted in the present study demonstrated that larvae of Capitella sp. I could discriminate between substrates based on their biochemical properties, especially between organic matter content and composition. The discriminative larval behavior observed in our study may be inferred to some extent from previous studies. For instance, larvae of Capitella sp. I preferentially choose where to settle and where to metamorphose based on substratum characteristics such as grain size (muddy substratum preferred over sand; Grassle et al. 1992), carbon content (organic-rich sediments preferred: Butman \& Grassle 1992), organic matter composition (nitrogen-rich sediments preferred: Thiyagarajan et al. 2005), hydrogen sulfide (serves as a larval settlement cue: Cuomo 1985) and oxygen concentrations (low ammonium and oxygen habitat preferred: Marinelli \& Woodin 2004). Although the role of hydrodynamics on larval habitat selection was not examined in the present study, larval reaction to hydrodynamics can substantially alter larval substratum selection behavior not only in Capitella sp. I (e.g. Snelgrove et al. 1993) but also in other invertebrates (barnacles: Mullineaux \& Garland 1993, Qian et al. 1999; abalone: Boxshall 2000; sabellariid polychaetes: Pawlik \& Butman 1993; oysters: Turner et al. 1994; seruplid polychaetes: Qian et al. 2000).

In Expt 1 of the present study, larvae did not show a preference for PC mud compared to the other 4 sites (Fig. 4). This was the case on all 4 sampling dates, suggesting that seasonal variations in the sediment biochemical properties at PC did not alter its unattractiveness to larvae. The unattractiveness of PC mud is probably not related to sediment physical characters, i.e. grain size distribution and water content, as these parameters were not significantly different from those at the other sites. In a previous study, we speculated that heavy metal pollution of PC mud might have inhibited larval metamorphosis at this site (Thiyagarajan et al. 2005). However, in the present study (see Table 1) there was no sign of heavy metal pollution at $\mathrm{PC}$ in comparison to the other sites. On the other hand, the overlying water at $\mathrm{PC}$ had higher concentrations of persistent organic pollutants such as PCB than at the other sites (Fong et al. unpubl. data). The Pearl River Estuary is likely to be a major source of PCB at the western side of Hong Kong (Wurla et al. 2006). The role of organic pollutants on the larval metamorphosis of this species has not yet been determined, but organic pollutants display a moderately negative effect on larval metamorphosis in another polychaete worm, Streblospio benedicti (Chandler et al. 1997).

An alternative explanation for the unattractiveness of PC mud may be that the low quantity or poor quality of organic matter might have repelled the larvae, i.e. this site had a significantly lower amount of all 6 biochemical parameters measured than VH (except the chl a level in August 2004). This argument was supported by our additional experiments. In Expt 3 the PC mud was enriched with proteins, carbohydrates or lipids and then offered to the larvae. Interestingly, protein and lipid enrichment treatments attracted significantly more larvae than the control (natural PC mud) (see Fig. 5D-I), suggesting that the unattractive factor for larvae may be related to organic matter rather than to the organic pollutants. Similarly, the unattractive property of PC mud was masked by attractive factors from $\mathrm{VH}$ mud in a concentration-dependent manner (Fig. 5A-C). The authors' unpublished data showed that if lipids were removed from the PC mud (by extraction), it attracted more larvae than the VH mud. Moreover, if lipids from the PC and VH muds were swapped, a higher number of larvae metamorphosed at PC than at VH. Among different types of lipids, unsaturated fatty acids serve as effective inducers of larval metamorphosis in polychaetes (Pawlik \& Faulkner 1986, Biggers \& Laufer 1996), but lipid types that inhibit polychaete larval metamorphosis have not yet been identified.

In our study, larvae preferred VH over the other sites on 2 out of 4 sampling dates (December 2004 and June 2005). Although all 6 biochemical properties measured at $\mathrm{VH}$ were not dramatically different from those at the other 3 sites (VHW, VHE and TLC) (see Fig. 2 \& 3), we expected a higher larval metamorphosis at $\mathrm{VH}$ because both $\mathrm{VH}$ and VHE received a substantial amount of raw sewage in the past, especially before the implementation of the Harbor Area Treatment (HAT) scheme in 2002 (EPD 2005). Our expectation was based on the fact that Capitella sp. I is a primary colonizer of organically enriched sediments in coastal areas throughout the world (Grassle \& Grassle 1976). Although the reason why they are associated with organically enriched sediments has remained unclear (Levin et al. 1996), the presence of excessive hydrogen sulfide (accompanied by reduced oxygen availability) in enriched sediments (i.e. VH mud) might be an attractive factor. In contrast, VHE mud did not attract more larvae than VH mud on 3 out of 4 sampling dates, and such a trend is difficult to explain without further study. 
Our results also showed a shift in larval preference with respect to sampling dates. For instance, a higher number of larvae metamorphosed in VHW mud in March 2005 than at other sites, except VH. On the other hand, only few larvae metamorphosed at VHW in December 2004 and June 2005. This shift in larval response to VHW mud with respect to sampling dates could be partially explained by the biochemical parameters measured in this study. In March 2005, protein content (both TN and EHAA) sharply increased at VHW as compared to the 3 other sampling dates. Proteins are indicators of an easily biodegradable fraction of organic matter and of food quality since they reflect specific availabilities of amino acids (Gremare et al. 1997). Although it looks like both the quantity and the composition of organic matter serve as larval metamorphosis cues, sediment-larval interaction represents a complex process and might be the result of multiple cues (Butman 1987). For instance, larvae of polychaetes are able to distinguish between different species of bacteria present in sediment and thus seem to be able to select habitats containing favourable species of bacteria (Gray 1966, 1974). Our study, however, was not designed to examine the precise relationship between particular biochemical features (or settlement cues) of sediments and larval metamorphosis (or juvenile performance). As we had expected from natural field samples, sediments used in the present study varied with respect to more than one biochemical factor at a time. Experimental manipulations of possible sedimentary larval settlement cues such as EHAA, protein and lipid components might help to elucidate the precise relationship between sedimentary cues and larval metamorphosis. The larval settlement pattern observed in our study may also have been influenced by many factors other than the biochemical properties of the sediment, i.e. larvae could have simply ignored some sites or been repelled by some sites, or larvae could have been killed and quickly decomposed before we made an observation. Larval preference with respect to bacteria present in the sediment samples, as previously found for archiannelids, copepods, polychaetes and gastropods (reviewed in Gary 1974), could also be responsible for the larval settlement pattern observed in our study, and experiments are underway to assess this possibility.

\section{Juvenile performance}

Several studies have documented the growth of Capitella sp. I in response to sediment organic matter (both quality and quantity) (reviewed by Snelgrove \& Butman 1994). This study reports, for the first time, the growth response of juveniles to natural variations in organic matter in surface sediments. In our study, $>65 \%$ of juveniles died within a period of $10 \mathrm{~d}$ postsettlement in sediment samples collected from PC, regardless of sampling dates, as opposed to low mortality $(<25 \%)$ during the same period and under the same culture conditions in sediment samples collected from other sites (e.g. TLC, VHE, VH and VHW). PC sediments differed from the other sites in that they had lower concentrations of TOC, TN and EHAA, and it may well be that the organic matter content (both in terms of quality and quantity) in the PC samples, despite seasonal variations, might be lower than the threshold level needed to support the survival of juvenile worms under our culture conditions. Adults, particularly early juveniles, are highly sensitive to food shortages (Tsutsumi et al. 2001). Although organic pollutant levels were not measured in this study, others have reported higher concentrations of several persistent organic pollutants (POP) in the waters at PC than at the other sites (J. Fong, P. K. S. Shin, R. R. S. Wu unpubl. data). The POP can reduce the growth of Capitella sp. I by as much as 50\% (Bridges et al. 1994, Foss \& Forbes 1997). Therefore, the observed high mortality of the juveniles at PC cannot be exclusively linked to organic matter.

In the present study, we recorded remarkable variation in juvenile growth with respect to sites within each sampling date and vice versa. For example, in August 2004, TLC supported higher growth than other sites. But in December 2004 and June 2005, juvenile worms grew faster at VH. Notably, in March 2005, worms attained dramatically higher growth at VHW than at other sites. As an exception, juveniles grew more slowly at PC regardless of sampling dates. Among different measures of organic matter quality, the biometric technique used by Mayer et al. (1995), EHAA concentration, was suggested to be one of the best indicators of the nutritional quality of sediment for benthic organisms (Linton \& Taghon 2000). Although it appears that spatio-temporal variations in the biochemical properties of the sediment (e.g. protein content) played a key role in producing the observed variation in juvenile growth among different sediment samples, this variation cannot solely be explained by the organic matter content (i.e. TOC) and composition (i.e. EHAA concentrations) alone because there was no significant temporal variation in EHAA concentrations at either TLC or $\mathrm{VH}$, and juveniles grew larger at TLC only in August 2004. Similarly, juveniles grew significantly larger at $\mathrm{VH}$ on only 3 out of 4 sampling dates. Thus, it seems juvenile performance of Capitella sp. I was controlled by factors other than those measured in this study. For instance, as previously discussed, persistent organic pollutants may also have played a potential role in reducing their growth performance, especially at PC. 
Additionally, site-specific growth of chemoautotrophic bacteria during the experimental period may have confounded our results. Juveniles of this species can utilize carbon sources produced by chemoautotrophic bacteria (Tsutsumi et al. 2001). For instance, sediment samples from $\mathrm{VH}$ had a higher level of sulfide than those from the other sites (Thiyagarajan et al. 2005), which might have promoted the growth of chemoautotrophic bacteria and, in turn, the growth of juveniles. Nevertheless, our results along with those from several previous studies (Gremare et al. 1988, Forbes \& Lopez 1990, Bridges et al. 1994) clearly demonstrate that sediment protein content is one of the key components of growth regulators in Capitella sp. I. This was the case in other polychaetes as well (e.g. Rossi \& Lardicci 2002). In fact, juvenile growth not only depends on protein content but also on the source of protein (Linton \& Taghon 2000), a topic of investigation which was not addressed in this study.

\section{Can larvae assess the quality of the habitat prior to their settlement?}

Planktonic larvae of sessile marine invertebrates presumably maximize their chances of good postsettlement performance by responding to habitatspecific cues, as settlement in a preferred habitat should provide them with shelter and food during the vulnerable juvenile life-history phase (reviewed in Pawlik 1992, Olafsson et al. 1994, Snelgrove \& Butman 1994, Gosselin \& Qian 1996). To date, these concepts are supported by a wide variety of organisms that include crabs (Stevens 2003), sea anemones (Sebens 1982), mussels (Petersen 1984), gastropods (Stoner et al. 1996), limpets (McGee \& Targett 1989) and clams (Snelgrove et al. 1998). The same line of reasoning is supported by the present study, where Capitella sp. I showed a specific preference for a substrate that is closely linked to its juvenile requirements. For instance, larvae did not choose to settle and metamorphose in PC mud, where juvenile growth was poor and mortality was substantially higher. Instead, they choose to metamorphose on substrates where juveniles grew faster and experienced less mortality, e.g. in $\mathrm{VH}$ mud in December 2004 and June 2005, and in VH and VHW mud in March 2005. However, larvae belonging to this species did not make the right choice on every occassion. For example, their larvae did not settle on substrates with a high portion of organic matter (possibly with higher levels of hydrogen sulfide) that would have supported higher juvenile growth (Cohen \& Pechenik 1999). Nevertheless, the current study presents evidence to support the hypothesis that larvae of Capitella sp. I can choose a habitat that supports higher post-settlement growth and survivorship.

\section{Ecological implications}

A high degree of spatial variability was evident in the abundance of Capitella spp. in the study area (see Fig. 7). They were found at extremely low densities at PC, while relatively higher densities were found at $\mathrm{VH}$, where pollution by sewage discharge is clearly evident. This striking spatial distribution pattern might be a result of the following processes: (1) pre-settlement, (2) settlement and metamorphosis, and (3) postsettlement growth and survival. In this study, the presettlement processes such as larval availability were not measured in the study area. Also, Capitella spp. has several sibling species and the proportion of Capitella sp. I in that complex in our study area is not yet known . Nevertheless, both the larval metamorphosis and juvenile performance (both growth and survival) pattern observed in our laboratory study correlated well with patterns of adult Capitella spp. distribution in the field, with the lowest abundance, metamorphosis, juvenile growth and survival at PC. Previous studies have pointed out the importance of larval habitat selection and post-settlement performance in determining the distribution of adult Capitella sp. populations (Butman 1987). The present study suggests, therefore, that the distribution of this species and possibly the species composition in macrobenthic communities are at least partly determined by the habitat preferences of larvae as well as by differential juvenile growth and mortality.

\section{CONCLUSIONS}

This study demonstrated for the first time a link between the biochemical properties of sediment, larval metamorphosis and juvenile growth performance in the opportunistic polychaete Capitella sp. I under laboratory conditions. Our results also demonstrated that larval metamorphosis can vary among sites of contrasting environments and these may have a close bearing upon the resultant spatial distribution of benthos. However, our conclusions must be viewed with caution since soft-bottom environments in the field are highly complex and confounded by hydrodynamics and intraand interspecific interactions, which may also affect larval metamorphosis and subsequent juvenile performance.

Acknowledgements. We thank X. D. Li (The Hong Kong Polytechnic University) for heavy metal data. We are grateful to J. A. Pechenik (Tufts University) and S. A. Woodin (University of South Carolina) for discussions during the initial course of this project. We thank J. S. Gray (Oslo University), R.S.S. Wu (City University of Hong Kong) and H. U. Dahms (HKUST) for 
their comments. We also thank L. Nelson (City University of Hong Kong) for enumeration of Capitella spp. in field samples. We are grateful to anonymous reviewers for their valuable suggestions. The work described in this paper was substantially funded by a grant from the Hong Kong Research Grants Council (Project No. CityU 1129/04M), and partially funded by the Area of Excellence Scheme under the UGC of the Hong Kong SAR (Project No. AoE/P-04/2004).

\section{LITERATURE CITED}

Biggers WJ, Laufer H (1996) Detection of juvenile hormoneactive compounds by larvae of the marine annelid Capitella sp. I. Arch Insect Biochem Physiol 32:475-484

Boxshall AJ (2000) The importance of flow and settlement cues to larvae of the abalone, Haliotis rufescens Swainson. J Exp Mar Biol Ecol 254:143-167

Bridges TS, Levin LA, Cabrera D, Plaia G (1994) Effects of sediment amended with sewage, algae, or hydrocarbons on growth and reproduction in two opportunistic polychaetes. J Exp Mar Biol Ecol 177:99-119

Butman CA (1987) Larval settlement of soft-sediment invertebrates: the spatial scales of pattern explained by active habitat selection and the emerging role of hydrodynamical processes. Oceanogr Mar Biol Annu Rev 25:113-165

Butman CA, Grassle JP (1992) Active habitat selection by Capitella sp. I larvae. I. Two-choice experiments in still water and flume flows. J Mar Res 50:669-715

Chandler GT, Shipp MR, Donelan TL (1997) Bioaccumulation, growth and larval settlement effects of sediment-associated polynuclear aromatic hydrocarbons on the estuarine polychaete, Streblospio benedicti (Webster). J Exp Mar Biol Ecol 213:95-110

Cohen RA, Pechenik JA (1999) Relationship between sediment organic content, metamorphosis, and postlarval performance in the deposit-feeding polychaete Capitella sp. I. J Exp Mar Biol Ecol 240:1-18

Cuomo MC (1985) Sulphide as a larval settlement cue for Capitella sp. I. Biogeochemistry 1:169-181

EPD (Environmental Protection Department) (2005) Marine water quality Hong Kong. Hong Kong SAR Government. Available at: epic.epd.gov.hk

Fabiano M, Danovaro R, Fraschetti S (1995) Temporal trend analysis of the elemental composition of the sediment organic matter in subtidal sandy sediments of the Ligurian Sea (NW Mediterranean): a three year study. Cont Shelf Res 15:1453-1469

Forbes TL, Lopez GR (1990) The effects of food concentration, body size, and environmental oxygen tension on the growth of the deposit-feeding polychaete, Capitella sp. I. Limnol Oceanogr 35:1535-1544

Foss HE, Forbes VE (1997) Effects of the polycyclic aromatic hydrocarbon fluoranthene on growth rate and nucleic acid composition of Capitella sp. I. Mar Biol 129:489-497

Gosselin LA, Qian PY (1996) Early post-settlement mortality of an intertidal barnacle: a critical period for survival. Mar Ecol Prog Ser 135:69-75

Grassle JP, Grassle JF (1976) Sibling species in the marine pollution indicator Capitella (Polychaeta). Science 192:567-569

Grassle JP, Butman CA, Mills SW (1992) Active habitat selection by Capitella sp. I larvae. II. Multiple-choice experiments in still water and flume flows. J Mar Res 50: $717-743$

Gray JS (1966) The attractive factor of intertidal sands to Protodrilus symbioticus. J Mar Biol Assoc UK 46:627-645
Gray JS (1974) Animal-sediment relationships. Oceanogr Mar Biol Annu Rev 12:223-261

Gremare A, Marsh AG, Tenore KR (1988) Short-term reproductive response of Capitella sp. I (Annelida: Polychaeta) fed on different diets. J Exp Mar Biol Ecol 123:147-162

Gremare A, Amouroux JM, Chrles F, Dinet A and 7 others (1997) Temporal changes in the biochemical composition and nutritional values of the particulate organic matter available to surface deposit feeders: a two year study. Mar Ecol Prog Ser 150:195-206

Hadfield MG, Paul VJ (2001) Natural chemical cues for the settlement and metamorphosis of marine invertebrate larvae. In: McClintock JG, Baker BJ (eds) Marine chemical ecology. CRC Press, Boca Raton, FL, p 431-461

Hartree EF (1972) Determination of protein: a modification of the Lowry method that gives a linear photometric response. Anal Biochem 48:422-427

Hu SI, Horng CY, Cheng IJ (2003) The use of growth and ingestion rates of Capitella sp. I as the bioassay approaches to determine the sediment quality of coastal wetland of Taiwan. J Exp Mar Biol Ecol 297:179-202

Hung JJ, Lin PL, Liu KK (2000) Dissolved and particulate organic carbon in the southern East China Sea. Cont Shelf Res 20:545-569

Levin L, Gaswell HL, Bridges T, DiBacco C, Cabrera D, Plaia G (1996) Demographic responses of estuarine polychaetes to pollutants: life table response experiments. Ecol Appl 6:1295-1313

Linton DL, Taghon GL (2000) Feeding, growth, and fecundity of Capitella sp. I in relation to sediment organic concentration. Mar Ecol Prog Ser 205:229-240

Loftis ME, Carpenter JH (1971) A fluorometric method for determining chlorophylls a, b and c. J Mar Res 29:319-338

Marinelli RL, Woodin SA (2004) Disturbance and recruitment: a test of solute and substrate specificity using Mercenaria mercenaria and Capitella sp. 1. Mar Ecol Prog Ser 269: $209-221$

Marsh JB, Weinstein DB (1966) Simple charring method for determination of lipids. J Lipid Res 7:574-576

Mayer LM, Schick LL, Sawyer T, Plante CJ, Jumars PA, Self RFL (1995) Bioavailable amino acids in sediments: a biomimetic, kinetics-based approach. Limnol Oceanogr 40:511-520

McGee BL, Targett NM (1989) Larval habitat selection in Crepidula (L.) and its effect on adult distribution patterns. J Exp Mar Biol Ecol 131:195-214

Mullineaux LS, Garland ED (1993) Larval recruitment in response to manipulated field flows. Mar Biol 116:667-683

Olafsson EB, Peterson CH, Ambrose WG (1994) Does recruitment limitation structure populations and communities of macro-invertebrates in marine soft-sediments: the relative significance of pre- and post settlement processes. Oceanogr Mar Biol Annu Rev 32:65-109

Pawlik JR (1992) Chemical ecology of the settlement of benthic marine invertebrates. Oceanogr Mar Biol Annu Rev 30:273-335

Pawlik JR, Butman CA (1993) Settlement of a marine tube worm as a function of current velocity: interacting effects of hydrodynamics and behavior. Limnol Oceanogr 38:1730-1740

Pawlik JR, Faulkner DJ (1986) Specific free fatty acids induce larval settlement and metamorphosis of the reef-building tube worm Phragmatopoma californica (Fewkes). J Exp Mar Biol Ecol 102:301-310

Petersen JH (1984) Larval settlement behavior in competing species: Mytilus californianus Conrad and $M$. edulis L. J Exp Mar Biol Ecol 82:147-159 
Pusceddu A, Sara G, Armeni M, Fabiano M, Mazzola A (1999) Seasonal and spatial changes in sediment organic matter composition of a semi-enclosed marine system (WMediterranean Sea). Hydrobiologia 397:59-70

Qian PY (1994) Effect of food quantity on growth and reproductive characteristics of Capitella sp. (Annelida: Polychaeta). Int J Invert Reprod Dev 26:175-185

Qian PY, Rittschof D, Sreedhar B, Chia FS (1999) Macrofouling in unidirectional flow: miniature pipes as experimental models for studying the effects of hydrodynamics on invertebrate larval settlement. Mar Ecol Prog Ser 191:141-151

Qian PY, Rittschof D, Sreedhar B (2000) Macrofouling in unidirectional flow: miniature pipes as experimental models for studying the interaction of flow and surface characteristics on the attachment of barnacle, bryozoan and polychaete larvae. Mar Ecol Prog Ser 207:109-121

Rossi F, Lardicci C (2002) Role of the nutritive value of sediment in regulating population dynamics of the depositfeeding polychaete Streblospio shrubsolii. Mar Biol 140:1129-1138

Sebens KP (1982) Recruitment and habitat selection in the intertidal sea anemones, Anthopleura elegantissima (Brandt) and A. xanthogrammica (Brandt). J Exp Mar Biol Ecol 59:103-124

Shin PKS, Ellingsen KE (2004) Spatial patterns of soft-sediment benthic diversity in subtropical Hong Kong waters. Mar Ecol Prog Ser 276:25-35

Snelgrove PVR, Butman CA (1994) Animal-sediment relationships revisited: cause versus effect. Oceanogr Mar Biol Annu Rev 32:111-177

Snelgrove PVR, Butman CA, Grassle JP (1993) Hydrodynamic enhancement of larval settlement in the bivalve Mulinia lateralis (Say) and the polychaete Capitella sp. I in microdepositional environments. J Exp Mar Biol Ecol 168:71-109

Snelgrove PVR, Grassle JP, Butman CA (1998) Sediment choice by settling larvae of the bivalve, Spisula solidissima (Dillwyn), in flow and still water. J Exp Mar Biol Ecol 231:171-190

Editorial responsibility: Howard Browman (Associate Editorin-Chief), Storebø, Norway
Snelgrove PVR, Grassle JP, Zimmer CA (2001) Adult macrofauna effects on Capitella sp. I larval settlement: a laboratory flume study. J Mar Res 59:657-674

Stevens BG (2003) Settlement, substrate preference, and survival of red king crab Paralithodes camtschaticus (Tilesius, 1815) glaucothoe on natural substrata in the laboratory. J Exp Mar Biol Ecol 283:63-78

Stoner AW, Ray M, Glazer RA, McCarthy KJ (1996) Metamorphic responses to natural substrata in a gastropod larva: decisions related to postlarval growth and habitat preference. J Exp Mar Biol Ecol 177:99-119

Thiyagarajan V, Soo L, Qian PY (2005) The role of sediment organic matter composition in larval habitat selection by the polychaete Capitella sp. I. J Exp Mar Biol Ecol 323:70-83

Tsutsumi H, Wainright S, Montani S, Saga M, Ichihara S, Kogure K (2001) Exploitation of a chemosynthetic food resource by the polychaete Capitella sp. I. Mar Ecol Prog Ser 216:119-127

Tsytsynum H, Fukunaga S, Fujita N, Sumida M (1990) Relationship between growth of Capitella sp. and organic enrichment of the sediment. Mar Ecol Prog Ser 63:157-162

Turner EJ, Zimmer-Faust MA, Palmer MA, Luckenbach M, Pentcheff ND (1994) Settlement of oyster Crassostrea virginica larvae: effects of water flow and a water-soluble chemical cue. Limnol Oceanogr 39:1579-1593

Underwood GJC, Paterson DM, Parkes RJ (1995) The measurement of microbial carbohydrate exoploymers from intertidal sediments. Limnol Oceanogr 40:12431253

Wong CKC, Yeung HY, Cheung RYH, Yung KKL, Wong $\mathrm{MH}$ (2000) Ecotoxicological assessment of persistent organic and heavy metal contamination in Hong Kong coastal sediments. Arch Environ Contam Toxicol 38: 486-493

Wurla O, Obbarda JP, Lam PKS (2006) Distribution of organochlorines in the dissolved and suspended phase of the sea-surface microlayer and seawater in Hong Kong, China. Mar Pollut Bull 52:768-777

Submitted: April 5, 2006; Accepted: June 5, 2006

Proofs received from author(s): November 19, 2006 